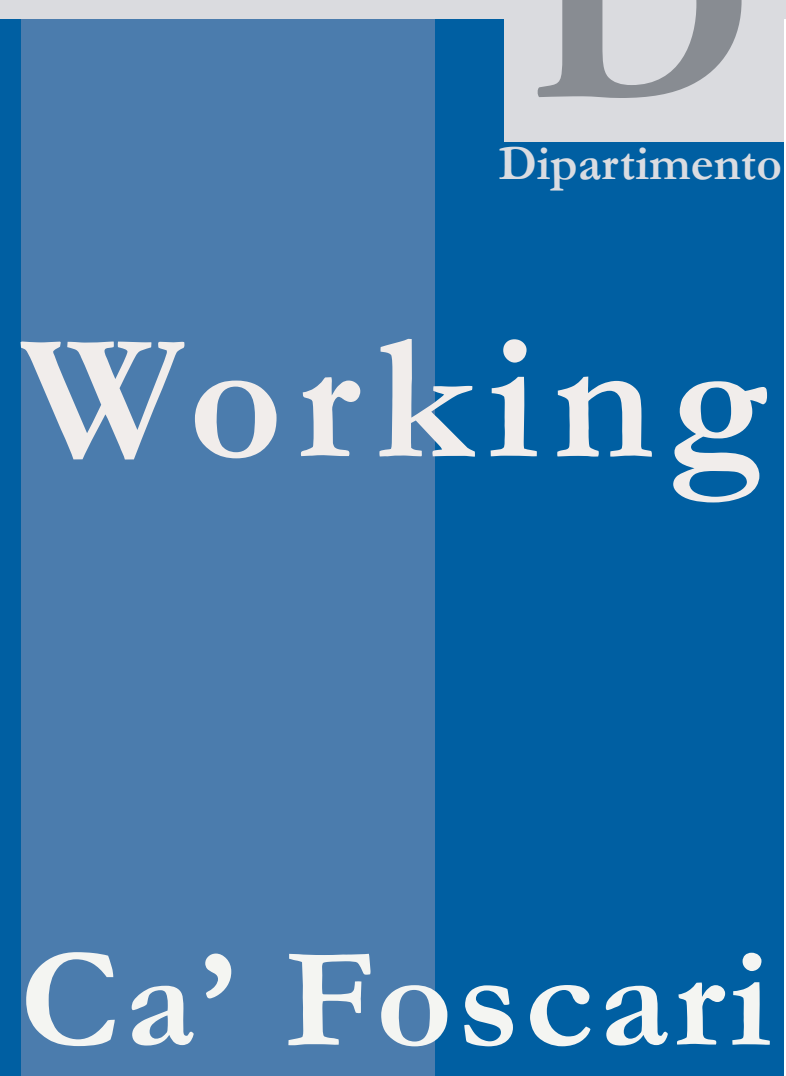

Scienze Economiche

Paper

Department

of Economics

University of

Venice

Paolo Crestanello

Giuseppe Tattara

Connections and Competences in the Governance of the Value Chain.

How Industrial Countries

Maintain their Competitive Advantage. 


\title{
Connections and Competences in the Governance of the Value Chain. How Industrial Countries Maintain their Competitive Advantage.
}

\author{
Paolo Crestanello \\ Poster e Crei, Vicenza \\ Giuseppe Tattara \\ Ca' Foscari University of Venice
}

\begin{abstract}
The aim of our paper is to analyse the governance of value chains operating in the traditional sectors of clothing and footwear, focusing particularly on production delocalization from the Italian region of Veneto to the nearby country of Rumania After describing and 'quantifying' the internationalization process between Veneto and Rumania we turn to discuss the possible consequences of this process, both for the region of origin and the recipient area. We highlight, through the concepts of linkages and competences how the production internationalization process may determine a progressive weakening of the network of linkages that characterize the home region, and discuss the main obstacles to a successful transfer of know-how and technologies to the host system.

From this discussion emerges the vision of some policy measures to amplify possible positive effects and counter negative consequences of the fragmentation of production, both in the home and in the host country.
\end{abstract}

\section{Keywords}

Internationalisation, Industrial districts, Delocalisation, Organization of Production

JEL Codes

F23, L22, L23, L67

Address for correspondence: Giuseppe Tattara Department of Economics Ca’ Foscari University of Venice Cannaregio 873, Fondamenta S.Giobbe 30121 Venezia - Italy

Phone: (++39) 0412349148 Fax: (++39) 0412349176 e-mail: tattara@unive.it

This Working Paper is published under the auspices of the Department of Economics of the Ca' Foscari University of Venice. Opinions expressed herein are those of the authors and not those of the Department. The Working Paper series is designed to divulge preliminary or incomplete work, circulated to favour discussion and comments. Citation of this paper should consider its provisional character.

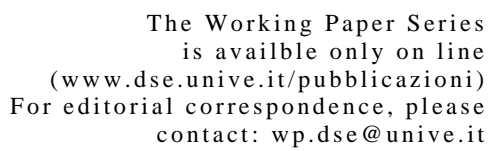

The Working Paper Series

is availble only on line (www.dse.unive.it/pubblicazioni)

For editorial correspondence, please

contact:wp.dse@unive.it

Department of Economics

Ca' Foscari University of Venice

Cannaregio 873, Fondamenta San Giobbe

30121 Venice Italy

Fax: ++390412349210 


\section{Connections and Competences in the Governance of the Value Chain. How Industrial Countries Maintain their Competitive Advantage ${ }^{1}$.}

The global economy has significantly changed during recent decades, and these changes are rooted in how the global economy is organized and governed. The development strategies of countries today are affected to an unprecedented degree by how industries are organized and transformed with consequences not only for the flows of goods and services across national borders, but also for the processes by which countries move up (or down) in the international system (Gereffi, 2005,160).

Production de-localization towards low wage countries is a strategy being followed with growing intensity by industrial countries seeking to compete with one another. The erosion of competitive advantages in international markets is being responded to by a combination of product upgrading and productivity increases at home and labour cost reduction abroad, through international fragmentation of production (Finger, 1975, 1977). Through such means, industrial countries in continental Europe, such as Germany and Italy, have been able to maintain their world market share, or at least prevent a drastic fall.

Such developments suggest the need for a new framework to understand both new patterns of competition among international firms and the development prospects of countries that are trying to upgrade their position in diverse global industries. The topic of the global economy is inherently interdisciplinary. Scholars in this field have to master 'the art of trespassing' (Hirschman 1981) and frequently cross the frontiers of established academic disciplines. In developing our theoretical framework along interdisciplinary lines we use two main analytical tools. Firstly, the concept of 'forward and backward linkages' that was devised by Hirschman in the fifties in his analyses of the problems of economic development (Hirschman, 1968). Secondly, the concept of 'competences' that emerged from the debate on industrial districts in Italy during the seventies (Brusco 1992, Becattini and Rullani 1996), derived from the tacit knowledge ideas of Polany (Polany, 1957) and the more recent elaborations of Nonaka and Tageuchi (1995).

The new aspects of modern world trade relevant to our discussion are (1) the rise of intra-industry and intra-product trade in intermediate inputs; (2) the ability of producers to 'slice up the value chain', in Krugman's (1995) phrase, by breaking a production process into many geographically separated steps; and (3) the emergence of a 'global production networks' framework that highlights how these emerging trends have altered governance structures and the distribution of gains in the global economy (Gereffi, 2005, 166).

This paper discusses the new patterns of production organisation by focussing on recent de-localization flows linking the Veneto, a manufacturing region of the Italian North East, and the East European country of Rumania. In fact, some Italian commentators speak of the Timisoara region of Rumania as the $9^{\text {th }}$

\footnotetext{
${ }^{1}$ This paper is part of the research program PRIN 2002-2003, n. 2002133972-03. We thank Frank Pyke for his careful reading and valuable comments.
} 
province of Veneto, because of the magnitude, the pervasiveness, and the rapid growth of such flows to this area (Berger and Locke, 2001).

I. The Management of the Global Value Chain : Linkages and Competences.

\section{I.1. Veneto manufacturing.}

In Italy the Veneto region is characterized by a presence of important brandowning final firms in footwear and clothing, supplied by a large network of small Italian subcontractors. These two sectors, footwear and clothing, are the focus of this paper, which draws upon Italian and Rumanian published data and some indepth interviews with clothing, footwear and textiles enterprises from a much larger sample carried out, both in Italy and in Rumania, by the authors in 2004 and 2005.

Many Italian final firms in the footwear and clothing industries have experienced over the last decade a strong production de-localization process towards low wage countries, mainly in Eastern Europe. Veneto enterprises have outsourced production abroad both by making direct investments (FDI) and also through international subcontracting relationships. The direct investment strategy has been adopted by many large enterprises that have acquired or established factories abroad, thereby moving away from participation in (quasi-market) subcontracting relationships to hierarchical relationships. This is the case, for example, of Geox, an important Veneto footwear producer, which in 1998 established its own large factory in Timisoara, Rumania, after changing from a previous strategy of using many sub-contractors.

The other strategy, international sub-contracting, is quantitatively more relevant than FDI, and is adopted mainly by small Veneto final firms that have replaced local Italian sub-contractors with foreign ones. Table 1 shows that Rumania was the most important country in Eastern Europe for Italian direct investments (FDI), in $2004^{2}$.

These figures for foreign direct investment explain only a part of the production de-localization phenomenon. They do not take into account the sub-contacting flows engaged in by Italian multinational firms, which are very important in the clothing and footwear industries ${ }^{3}$.

The production de-localization process can be measured according to three indicators: the amount of foreign direct investments, the number of firms owned

\footnotetext{
${ }^{2}$ Capital flows into Rumania have been fully liberalized since the early nineties. Direct investments in Rumania now amount to $4.7 \%$ of gross national income (The Economist, 2006). Investments, in large part, depend on the outsourcing processes of large manufacturing enterprises (such as Continental, Michelin, Daewoo, Renault, Sumitomo, Yazaki, and Panasonic) and distribution firms (such as Metro, Carrefour, Billa, and Unilever), as well as major European banks ("Survey on the Entrepreneurial Veneto Presence in Rumania"). In 1996, the biggest 25 Rumanian manufacturing factories controlled by foreign firms had a turnover of around 2000 million dollars. This amounts to $6 \%$ of the total turnover produced by private Rumanian firms.

3 On the effect of FDI see Navaretti, Falzoni,Turrini (1999) and Navaretti, Bruno, Castellani,Falzoni (2002). On the necessity to assess the magnitude of de-localization flows through the study of commodity flows, see, amongst others, Yeats (1998) and Kaminsky and $\mathrm{Ng}(2000)$.
} 
by foreign entrepreneurs, and the trade flows of finished and semi-finished products under the coordination and control of multinational firms ${ }^{4}$.

Table 1. Italian Foreign Direct Investments in Eastern Europe, 2004.

\begin{tabular}{|c|c|c|c|c|c|c|}
\hline & \multicolumn{3}{|c|}{$\begin{array}{l}\text { Number of enterprises where at least } \\
10 \% \text { of share capital is owned by Italian } \\
\text { companies }\end{array}$} & \multicolumn{3}{|c|}{$\begin{array}{l}\text { Percentage of enterprises where Italian } \\
\text { companies own more than } 50 \% \text { of } \\
\text { their share capital }\end{array}$} \\
\hline & Firms & Employees & Turnover & Firms & Employees & Turnover \\
\hline & n. & $\mathrm{n}$. & mil. $€$ & $\%$ & $\%$ & $\%$ \\
\hline Rumania & 729 & 55.806 & $2.614,6$ & 79,4 & 89,1 & 81,1 \\
\hline Russia & 157 & 53.347 & $2.050,0$ & 66,2 & 24,2 & 41,6 \\
\hline Poland & 391 & 37.743 & $5.522,3$ & 84,4 & 88,3 & 93,6 \\
\hline Hungary & 181 & 15.500 & $2.565,9$ & 85,6 & 77,5 & 63,5 \\
\hline Czech Republic & 151 & 15.328 & $2.850,4$ & 80,8 & 86,5 & 43,7 \\
\hline Bulgaria & 166 & 9.723 & 456,5 & 87,3 & 93,6 & 87,6 \\
\hline Slovakia & 123 & 8.610 & 508,8 & 83,7 & 66,9 & 69,6 \\
\hline Albania & 157 & 7.905 & 500,4 & 88,5 & 87,1 & 87,9 \\
\hline Slovenia & 101 & 5.743 & 579,2 & 77,2 & 77,7 & 82,0 \\
\hline Ukraine & 66 & 5.018 & 422,5 & 80,3 & 84,0 & 83,1 \\
\hline Serbia and Montenegro & 97 & 3.732 & 537,1 & 85,6 & 31,5 & 90,7 \\
\hline Croatia & 75 & 2.885 & 601,8 & 90,7 & 85,7 & 94,2 \\
\hline Other countries & 331 & 6.989 & 817 & 84,0 & 64,5 & 79,1 \\
\hline Total & 2.725 & 228.329 & $20.025,9$ & 82,1 & 70,0 & 73,6 \\
\hline
\end{tabular}

Source: CNEL, R\&P and Politecnico di Milano. The data base refers to Limited firms in mining, energy, manufacturing, and services, in which Italian companies own more than $10 \%$, or more than $50 \%$, of their share capital.

Some large Italian final firms have encouraged their domestic sub-contractors to move abroad in order to continue, at lower labour cost, the previous business relationships that they had in their country, and today here are many small firms managed by Italian entrepreneurs living in Rumania that work as subcontractors for multinational firms.

During the nineties, Italian clothing and footwear imports came mainly from Rumania, but by 2004 China had become the most important supplier for Italy in clothing, and the second, after Rumania, in footwear production. Nevertheless, Veneto remains highly dependent on imports from Rumania. Out of the total amount of Italian imports from Rumania in clothing and footwear in 2005, Veneto accounted for respectively 33\% and 52\%.

Out of 18,000 Italian firms registered in 2005 in Rumania, 3,900 have a 'Veneto origin', i.e. $22 \%$ of the total (this had risen from respectively 12,000 and 2,000 in 2002: Regione Veneto, $2006^{5}$ ). For this reason, Timisoara-Arad, a highly industrialized area that has experiencedfast development during the last ten years, is highly interdependent with Veneto. $45 \%$ of all Veneto firms that have moved production abroad are in Rumania, and $17 \%$ in China; Poland, Bulgaria and Tunisia follow at a distance (Capitalia, 2005, table D73).

The main advantage of Rumania for attracting foreign investments and subcontracting orders is that it has the lowest cost of labour amongst East European countries, that is $8 \%$ of the EU-15 average (Table 2).

\footnotetext{
${ }^{4}$ According to Dicken (2004) "a transnational company is a firm which has the power to coordinate and control operations in more than one country, even if does not own them”.

${ }^{5}$ These numbers include possible non- active units.
} 
Table 2. Clothing Manufacturing.Yearly Labour Costs in € per employee.

\begin{tabular}{|c|c|c|c|c|c|c|c|c|}
\hline & 1997 & 1998 & 1999 & 2000 & 2001 & 2002 & $\begin{array}{l}\text { \% of the } \\
\text { cost EU- } \\
15 \text { in } \\
2001\end{array}$ & $\begin{array}{c}\text { average } \\
\text { yearly } \\
\text { variation } \\
1997-02 \\
\end{array}$ \\
\hline The Czech Republic & 3436 & 3732 & 3817 & 4424 & 4843 & 5758 & 21.7 & 0,11 \\
\hline Hungary & 3417 & 3414 & 3608 & 3939 & 4382 & 5236 & 19.7 & 0,09 \\
\hline Lithuania & 2175 & 2413 & 2712 & 3016 & 3018 & - & 13.5 & $0,09 *$ \\
\hline Poland & 3270 & 3489 & 4247 & 4067 & 4683 & 4533 & 21.0 & 0,07 \\
\hline Slovakia & 2898 & 3318 & 2805 & 3296 & 3427 & 3640 & 15.4 & 0,05 \\
\hline Slovenia & 8095 & 8694 & 9000 & 9480 & 10023 & 10372 & 45.0 & 0,05 \\
\hline Bulgaria & 860 & 1114 & 1185 & 1267 & 1345 & 1418 & 6.0 & 0,11 \\
\hline Rumania & 1214 & 1478 & 1419 & 1715 & 1806 & 1831 & 8.1 & 0,09 \\
\hline EU-15 & - & - & - & - & 22282 & - & - & - \\
\hline
\end{tabular}

Source: CEPS-WIIW (2005, table 5a)

*1997-2001

The large scale of the production de-localisation of Veneto firms to Rumania can be explained by the availability of low cost labour, the geographical proximity of the two territories, and by the particular structure of the Veneto region's clothing industry. Veneto has a larger presence of firms producing standardized products in large batches (such as jeans and sports garments) than the other Italian regions, such as, for example, Emilia Romagna, where there is a focus on female fashion and high quality garments which makes delocalization abroad difficult. Such different product mixes explain the different historical patterns in the organization of production followed by the two regions (Crestanello 1996), although, under the pressure of demand for more fashionable and customized products, Veneto also is now rapidly moving towards producing less standard items and the differences with Emilia Romagna are lessening.

In Rumania, thousands of Veneto entrepreneurs and technicians control, both through foreign affiliates and local sub-contracting firms, respect for quality standards and delivery times for items produced to designs sent by home enterprises ${ }^{6}$.

\section{I.2. Rumania in the international market.}

In a backward country like Rumania, that has emerged 15 years after the fall of Ceaucescu and the associated Communist regime in many places -apart from the Buchares-Iflow and the Western regions - many markets still do not exist, or are at an initial stage, and are not regularly utilised. Knowledge about technology and the international market is scarce and incomplete. The legacy of a planned economy, together with a long-lasting period of economic uncertainty with slow growth occurring between 1990 and 1996, and a still partial privatization process, have not allowed markets to fully work. Furthermore, managerial competences are still scarce and inertia comes from a lack of self-organization and from a strong aversion to risk ${ }^{7}$. A manager of an ex-state large clothing factory, Rapsodia, told us:

\footnotetext{
6 In Rumania the number of firms controlled by Italian entrepreneurs, or working on behalf of Italian multinational enterprises, are estimated to be around 10,000-12,000.

7 According to the International Labour Office, between 1990 and 2000 industrial employment and wages of Rumanian workers declined (in real terms)(Laborsta in
} 
During the Communist regime the Rumanian clothing industry had 46 large plants with an average number of workers ranging from 2000 to 5000, and the country was split into three centrally organized districts. Production planning was centralized in Bucharest and all the products were produced on stock. Two collections were launched each year and presented at a fair in Bucharest that was visited by foreign buyers. Rumanian producers did not receive any foreign currency and all the production and distribution decisions were centrally planned. A bureaucratic commission fixed the sale prices without having direct information about production costs.

In 1989, all the Russian market was lost and the domestic one shrank because of a fall in employment and in real wages. A dramatic social and economic deterioration ensued that began to reverse only at the end of the nineties. In such a distressed situation it proved very difficult for Rumanian enterprises to enter the capitalist market and continue the few relations they had established with Western firms, mainly because of a lack of financial support and marketing experience. Many Rumanian clothing firms began working as sub-contractors for Western companies.

Table 3 shows that a few years after the fall of Ceaucescu, Rumania had almost completely lost the Soviet market, after Germany and Italy started to delocalize to that country part of their clothing and footwear production. Today, a large part of the Rumanian clothing industry is dedicated to the transformation of raw materials and semi-finished goods, mostly imported from Western Europe and re-exported towards those same countries at a more advanced level of manufacturing. This phenomenon is reflected, on the one hand, in the high levels of Rumanian clothing and footwear exports going to certain Western countries, and, on the other hand, in high quantities of imports of textiles and leather from these same countries (table 3, in bold). Only the products destined to the Russian market are manufactured with yarn, fabrics and leather bought directly by Rumanian firms in the domestic or international markets.

The trade data also show the growing importance of Italy as a trading partner for Rumania (Baldone, Sdogati,Tajoli 2001, 2002;Graziani, 1998, 2001), having replaced Germany as its the most important partner. Germany, however, has strengthened its own Rumanian presence in other higher capital-intensive industries, such as chemicals, electro-mechanics, optical instruments and transport $^{8}$.

wwww.ilo.org). In contrast, the Rumanian Central Statistical Office asserts that wages, during the nineties, registered a modest increase (Insee, various years). Anyway, as the strong employment reduction is not questioned, the employees' aggregate purchasing power has certainly declined.

${ }^{8}$ On the German position in respect to Eastern Europe, see Pellegrin (1997). 
Table 3. Rumanian Trade for Selected Products and Markets (values in million \$)

\begin{tabular}{|c|c|c|c|c|c|c|c|c|}
\hline \multirow[b]{2}{*}{1991} & \multirow[b]{2}{*}{ World } & \multicolumn{2}{|c|}{ Imports } & & & \multicolumn{2}{|c|}{ Exports } & \multirow[b]{2}{*}{ Ex-USSR } \\
\hline & & Italy & Germany & Ex-USSR $\mathrm{W}$ & orld & Italy & Germany & \\
\hline Textiles & 91,1 & 5,8 & 8,4 & 4,5 & 99,5 & 7,9 & 11,9 & 22,2 \\
\hline Clothing & 52,3 & 6,1 & 2,6 & 0,0 & 296,3 & 29,7 & 72,2 & 96,2 \\
\hline Tanned leather & 4,7 & 0,4 & 1,0 & 0,0 & 0,9 & 0,0 & 0,4 & 0,0 \\
\hline Footwear & 44,4 & 5,6 & 10,3 & 0,0 & 85,0 & 7,6 & 9,2 & 34,2 \\
\hline \multicolumn{9}{|l|}{2004} \\
\hline Textiles & $3.329,2$ & 1147,0 & 464,0 & 7,2 & 562,1 & 146,0 & 117,0 & $\overline{0,0}$ \\
\hline Clothing & 645,5 & 249,0 & 33,6 & 0,0 & 4417,3 & 1592,0 & 1027,0 & 6,9 \\
\hline Tanned leather & 762,1 & 600,0 & 29,6 & 0,0 & 80,7 & 31,8 & 12,3 & 0,0 \\
\hline Footwear & 387,8 & 271,1 & 7,0 & 0,0 & $1.512,5$ & 1092,7 & 89,6 & 0,0 \\
\hline
\end{tabular}

Source: http://unstats.un.org/unsd/comtrade.

\section{I.3. Links and Competences.}

Forward and backward linkages have been appropriately defined by Hirschman (1968, p. 48-50). Linkages are the result of a series of investment decisions, each dependent upon the other, taking place in the course of a process of economic development. Backward linkages take place when a final demand stimulates the production of inputs (semi-finished products, raw materials and machinery) necessary to the production process, while forward linkages develop from the production of an input to add other downstream products. Backward and forward linkages develop where there are prospects for profit for local entrepreneurs, and also where there are abilities to make products that can be sold on the market. Competences must also develop for the efficient production of machinery and raw materials required by the growing industry. The role of domestic competences, neglected initially by Hirschman (Brusco, Paba, 1992, p. 234), plays a crucial role in translating opportunities generated by the growth of demand into entrepreneurial actions ${ }^{9}$.

Important production links, that existed in the past in the Rumanian economy, need to be rebuilt. This is the case in the textiles industry that was important before 1989 but which was later largely abandoned because of the rapid technological obsolescence of its plants and the difficulty to produce the high quality yarns and fabrics required by the sophisticated Western market ${ }^{10}$. Many Rumanian textile firms have closed down and some have converted to clothing production. The EU, moreover, has promoted a custom agreement that makes it easy to import into Rumania raw materials and semi-finished products. In the

\footnotetext{
${ }^{9}$ In the 50's the economists' approach to the problems of economic development was centred on demand factors, while the supply capacity to respond to new entrepreneurial opportunities was neglected. Hirschman is aware of the importance of supply but decides not to focus on it. He explains that a more radical break with the paradigm came through suggestions that a determining influence on growth may issue from the production side of the economy. Sociologists like Bert Hoselitz and others took this point of view when they focused on the conditions for the emergence of entrepreneurship. "As an economist I preferred to simply assume an insufficiency of entrepreneurial motivation and then to systematically search for such constellations of productive forces as would move private or public decision makers to “do something” through special pressures" (1977, p. 70).

${ }^{10}$ A firm's textiles sample collection is generally necessary for a wide range of products, differentiated by the blend of material used, colours, the printing, and other aspects.
} 
nineties, imports from the EU were subject to OPT (outward processing trade ${ }^{11}$ ) provision, and then in 2000 were completely liberalized. Further, finished products were exported to the Efta countries without duties. Through such means, the EU countries have protected their textiles industries from the competition of important producers, such as Turkey, whose exports to Rumania are penalised by import tariffs ${ }^{12}$.

Consequently, after the fall of the Ceaucescu regime, not only was there a need for investments to renew machinery and textiles production, but foreign investors could import into Rumania all the raw materials they required, enjoying low tariffs $^{13}$. Exactly the same process occurred in the tanning industries with the closure, during the nineties, of nearly all the Rumanian firms ${ }^{14}$.

Table 4 shows the strong employment and production reductions that occurred in the Rumanian manufacturing industries between 1990 and 2001. The restructuring process has affected the textiles and the footwear industries much more than the clothing industry - which has maintained stable employment. Between 1990 and 2001 these three industries altogether lost 316,000 jobs. The aggregate data nonetheless do not fully reflect the extent of the restructuring which has occurred , involving the closure of many State companies and radical changes in labour and production organization.

Table 4. Production Values and Employment in Rumania. Selected Industrial Sectors. Turnover in Billions of Lei, at Current Prices.

\begin{tabular}{lrrrrrrrrr}
\hline & \multicolumn{3}{c}{ Production } & & & \multicolumn{4}{c}{ Employees } \\
& Textiles & Clothing & Footwear $\begin{array}{l}\text { Manufacturir } \\
*\end{array}$ & & & Textiles & Clothing & Footwear & Manufacturing* \\
\hline 1990 & 78 & 40 & 20 & 1.076 & 414.000 & 258.000 & 127.000 & 3.452 .000 \\
& $7 \%$ & $4 \%$ & $2 \%$ & 100 & $12 \%$ & $7 \%$ & $4 \%$ & 100 \\
1998 & 8.880 & 9.224 & 4.108 & 252.570 & 128.000 & 239.000 & 76.000 & 1.907 .000 \\
& $4 \%$ & $4 \%$ & $2 \%$ & 100 & $6 \%$ & $17 \%$ & $5 \%$ & 100 \\
2001 & 23.454 & 37.966 & 14.420 & 749.760 & 98.000 & 290.000 & 98.000 & 1.590 .000 \\
& $3 \%$ & $5 \%$ & $2 \%$ & 100 & $6 \%$ & $18 \%$ & $6 \%$ & 100 \\
Var. '90-'01 & - & - & - & - & -316.000 & 32.000 & -29.000 & 1.862 .000 \\
\hline
\end{tabular}

Source: Insse (2003), 3.1.11, and 9.9. 2001is the last year available for production data.

(*) Without building, energy and mining.

\footnotetext{
11 The outward processing trade constitutes a customs procedure by which goods that are exported from a specified territory of a specific country for the purpose of being processed within a designated period of time, to be followed by the subsequent re-importation of products manufactured from the exported goods, are eligible for complete or partial exemption from customs duties and taxes.

${ }^{12}$ Hirschman notices that imports play a creative role in the process of development but that the "exporting countries can make political and economic pressure in order to prevent or delay the loss of important markets” (1968, p. 151).

${ }^{13}$ See Chakravarthi Raghavan da Ginevra 7 Dec, 1995 in www.sunsonline.org/trade/process/followup/1995/12060095.htm. See also UN's Economic Commission for Europe (ECE), Economic Bullettin, v. 47, 1995.

${ }^{14}$ This was a case of non-existent or negative consumption linkages. As Hirschman had noticed: "it is now widely recognised that during the first phase of export expansion in the countries of the periphery an important effect is not the creation of new industries to satisfy rising consumer demand, but the destruction of established handicraft and artisan activities....as new imports of consumer goods compete successfully against them” (1977, p. 72-73)
} 
Today, however, profit opportunities in textiles production in Rumania have grown, clearly as a consequence of downstream demand increases, and the effect of foreign investors starting up textiles production at the local level. For example, a firm in Botosani, controlled by the French Cantex Group, has set up a new local factory to supply high quality fabric. The same has happened in Zalau with Samtex - owned by the Italian Campagnolo group - that now produces and dyes good quality jersey, partially used directly, but mainly sold to Italian firms that subcontract sports clothing in Rumania. Since fabric supply is the most important input in the clothing chain, a country that wants to upgrade its position in the value chain needs to develop an adequate textiles industry. In Rumania, the process - if a process will develop - is just in its infancy, and currently the greater part of textiles is imported from abroad.

Some capital-intensive stages of the clothing production process, such as for example washing and printing have a cost in Rumania close to the cost in Italy, but have been recently established in Rumania under pressure from foreign firms that need to complete in that country their value chains and ship the finished product (already checked and packed) to Italy. Sometimes these firms are established by small Italian entrepreneurs, who, following their customers' internationalisation process and their suggestions, have transferred abroad their own manufacturing activities. This has made it possible for Gas, an Italian firm that controls in Rumania an important production factory, and for Benetton, that has an important ready dyed sweater production, to complete abroad the product cycle, ironing and wrapping included. If the Rumanian economy could develop its clothing value chain, so that a larger share of the international industrial organization might be supplied by Rumanian firms, this country would acquire a significant competitive advantage in respect to other sub-contractors in Eastern European and North Africa that are in competition to attract investments from abroad.

At present, in Rumania, the supply of raw materials and capital goods for the clothing and footwear industry comes mainly from foreign countries, while generally the domestic market only offers some basic inputs, and some repair and maintenance activity. Rumania lacks able craftsmen that can quickly intervene in the event of a machine breakdown, with the consequence that for firms to ensure that they can maintain production they are forced to hold some machines in reserve in case it should be necessary to replace those that are out of use. Moreover, the modest price which foreign customers pay in Rumania for semifinished products does not permit local firms to develop an adequate financial capability to amortize the costs of modern machines. The machinery used is in fact older than that in use in Veneto plants.

How is it that people in charge of the maintenance of the numerous textiles plants during the Ceaucescu regime did not at the time of the overthrowing constitute a fertile humus in which the germs of a small mechanical industry could develop? A director of Samtex s.s. tells us:

[During the Communist era] the maintenance of textiles plants was regularly carried out by well-equipped internal teams. However, by the time of Ceaucescu's fall, the demand for textiles yarns had drastically diminished, exstate firms had not been investing in new plants because of both a lack of demand 
and of finance, and when there was a breakdown the looms were not repaired but were substituted by other looms set aside that were not in use. Consequently, the maintenance teams were not needed and were the first to be dismantled, and many mechanical workers were fired and emigrated.

Of course, a lack of demand for maintenance does not fully explain the backwardness of the Rumanian mechanical industry, that lost in the five years after independence $50 \%$ of its employees, around 300.000 workers, but this story highlights the role played by the impoverishment of the country's manufacturing base in the early 90s, due to the heavy industrial restructuring and large emigration flows of skilled workers.

Forward linkages develop when a foreign firm places an order for all or part of its production to a Rumanian supplier, that produces itself or subcontracts to other local firms. In the case of a clothing firm, for example, it would require that a Rumanian firm provides - in addition to other upstream production stages such as cutting and sewing -, also quality control, packing, shipping and logistic operations. Since Rumanian firms typically are restricted to receiving from foreign enterprises semi-finished products to be processed, forward linkages are still generally weak. In many cases transport services for Italian buyers in Rumania are supplied by Italian firms, and even the packing cases are imported through the OPT regime from Italy.

In short, opportunities for developing, through the de-localisation process, upstream and downstream industries are only providing a weak stimulation to the birth of an autonomous domestic entrepreneurship. It is the lack of technical competences, and also of local managers that, on the one hand, necessitate high imports of intermediate products and services, while, on the other hand, leave the potentialities for internal production unfulfilled, unable at the present to substitute for foreign production ${ }^{15}$.

We are speaking about backward and forward linkages that can be established in respect of a product designed by a foreign enterprise to be sold in the export market. The role of the home market in favouring economic development is crucial, as the existence of an effective and perceivable domestic demand renders profit opportunities visible and real. In its absence the position of local subcontractors is very weak as they depend on foreign buyers and do not have autonomy $^{16}$. Products demanded in the Rumanian domestic market are totally unsophisticated and very different, in terms of price and quality, from those sold in the international market. Even the distribution circuit is different ${ }^{17}$. Prices are kept low because of the population's poor consumption power and the fierce competition of standardised cheap products imported from China and India.

\footnotetext{
${ }^{15}$ A high flow of intermediate imports, according to Hirschman, is a clear indicator of the existence of a potential market; consumers and firms that buy the imported goods could purchase similar goods were they domestically produced.

${ }^{16}$ See Hirschman (1968). For an East Asian perspective see Ginzburg and Simonazzi (2003) and Akamatsu (1962). Gereffi (2005, 171ff.) relates the fascinating history of the upgrading of East Asian sub-contractors in the clothing sector. .

${ }^{17}$ Consumption goods imported by Western European countries do not compete with production for the domestic market and the two production structures, that of Western European countries and that of Balkan Europe, remain very different.
} 
The manager of Filty, a large Rumanian footwear company in Timisoara with 1400 employees that, before the nineties, produced exclusively for the home market and for the Comecon countries and today works almost exclusively as a subcontractor on behalf of Western enterprises, asserts:

Our company produces for the home market approximately $5 \%$ of its production and sells it at a price so low that it covers only the cost of labour; we do this only in periods of production capacity underutilisation

The production planning and commercialization of clothing or footwear products requires various types of skills, such as: being able to collect and analyse information on market trends; a knowledge of distribution channels and methods; brand promotion capabilities; and the capacity to devise a price policy capable of supporting the manufacture of products exhibiting quality and style. This is knowledge that enterprises acquire in the first place through the process of selling on the home market. But this process of learning is still weak in Rumania, which has, together with Bulgaria, the poorest East European consumption markets. In this country, the disposable income per capita is in fact only $40 \%$ of the Polish income, and $37 \%$ and $18 \%$ of the Hungarian and Slovenian incomes, ${ }^{18}$ and it has not changed in the course of the nineties. The distribution of employee wages has become more unequal through time with a rapid increase in the number of employees that belong to the lower deciles (Insee, 2001,ch. 9 and 3).

A rising income induces in turn a more sophisticated demand and this influences the supply. In other words, a sophisticated consumer creates a sophisticated producer $^{19}$. This occurs not only as a result of the obvious demand stimulation, but also because inside a company, as an entrepreneur of Vigevano (Veneto) who's firm has been transplanted into Rumania explained to us, workers in a country of poor consumers do not care for the quality of the product, and do not give attention to the details, while an Italian worker, who is a sophisticated consumer, surely would so do.

The demand factor is therefore important, but it can also happen that a backward region does not have at its disposal all the skills necessary to exploit production opportunities. A high importation of intermediate products indicates the existence of a potential market: consumers or importing firms could buy them on the domestic market if someone was able to produce them at an attractive price. However, despite the presence of a potential demand, some production sequences will not take place if the country lacks the necessary skills and technologies. This is particularly likely to be the case when a complex, refined product requires the employment of modern expensive technologies ${ }^{20}$, and when needed semi-

\footnotetext{
${ }^{18}<$ http://web.worldbank.org/WBSITE/EXTERNAL/DATASTATISTICS/0,,menuPK:232599 pagePK:64133170 piPK:64133498 theSitePK:239419,00.html>

${ }^{19}$ As noted by Porter, the level and quality of domestic demand is one of the factors in the competitive advantage of an industry. As the author says "demanding buyers put pressureon domestic firms to satisfy high quality product and service standards”(Porter, 1990, p.117).

${ }^{20}$ In such a case the maintenance of the technologies might require the employment of foreign technicians. The lack of adequate maintenance is considered by Hirschman (1969, p.170) "one of the most problematic problems for any developing country". Hirschman continues saying that once the problem has been picked up, the most direct way out of it is to launch production processes that do not require maintenance, or on the opposite, that require a very
} 
finished components and raw materials cannot be found on the local market and can be easily imported. In many cases the competence increase is limited to a better trade acquaintance by the importers, and involves the development of little familiarity with advanced production techniques.

In the case of Rumania, the process of production de-localization from Italy and other countries of Europe has made possible a local production of sophisticated products. All this has happened thanks to the presence in that country of numerous enterprises and Italian technicians. A transfer of tacit competences occurs through the movement from Italy to Rumania of technicians and entrepreneurs who transmit their knowledge, resolve practical problems, correct errors, and put into operation the best production techniques.

Subcontracting interacts with local competences in a different way than foreign investments. Subcontracting stimulates local managerial resources to organize themselves, to relate to foreign customers, to produce sophisticated products, to respect strict delivery times and solve cost management problems - although sometimes the result is not efficient and foreign customers are not satisfied.

Italian entrepreneurs' judgements about the performance of the Rumanian worker are very varied. Italian entrepreneurs who have had their own firms in Rumania for several years, and who have trained their own Rumanian workers, are mostly satisfied, while entrepreneurs who rely on local subcontractors managed by Rumanians, tell of organisational disfunctions - an unsatisfactory situation that rarely develops into a stable form of collaboration.

\section{I.4. The importance of the delocalization process from Veneto to Rumania.}

A picture of the magnitude of delocalization from Veneto to Rumania is provided by figures showing the importance of the value of Veneto clothing and footwear imports from Rumania, and others showing the large number of jobs created there.

According to the Rumanian customs office, 98\% of total clothing, and 95\% of footwear, exported from Rumania to all countries, were produced as a result of OPT trade, in 2003. Let us assume that imports into the Veneto region in clothing and footwear are totally under the control of Veneto manufacturing firms (not sold directly in the final market). It means in 2005 a value respectively for the two sectors of 439 and 464 million of euros, including raw materials and subcontracting value added. In clothing firms, in Rumania, raw materials constitute on average $75 \%$ of the value of the final product, so that the value added produced in Rumania corresponding to a final value of 439 million euros (exports to Veneto) is 110 million euros. This corresponds to 31.400 jobs, assuming an average turnover value per employee of 3500 euros. In footwear factories, raw materials represent a larger quota of the final value and the corresponding estimated jobs are 26.000 (table 5).

rigorous and compulsory maintenance programme, that once put into practice, can play a positive role in the process of economic development (p. 172). This seems not to be the Rumanian case, although a positive development along these lines is not to be ruled out completely. 
Table 5. Rumanian jobs created by the Veneto otusourcing and 'equivalent' jobs in Veneto. Clothing and Footwear. 2005.

\begin{tabular}{|c|c|c|c|}
\hline & & $\begin{array}{l}\text { Clothing/ } \\
\text { Knitwear }\end{array}$ & Footwear \\
\hline Veneto Imports from Rumania & Millions $€$ & 439 & 464 \\
\hline Rumanian Subcontractors: Raw materials/Turnover & $\%$ & 75 & 80 \\
\hline Veneto Subcontractors: Raw materials/Turnover & $\%$ & 50 & 50 \\
\hline Turnover/employee in Rumanian subcontractors & $€$ & 3.500 & 3.500 \\
\hline Turnover/employee in Veneto subcontractors & $€$ & 20.000 & 20.000 \\
\hline Raw materials exported from Veneto to Rumania in OPT & Millions $€$ & 329 & 371 \\
\hline Rumanian subcontractors value added & Millions $€$ & 110 & 93 \\
\hline Value added in Veneto necessary to transform OPT exported raw materials & Millions $€$ & 329 & 371 \\
\hline Jobs in Rumania connected with OPT trade & n. & 31.357 & 26.514 \\
\hline Equivalent jobs in Veneto & n. & 16.462 & 18.560 \\
\hline
\end{tabular}

If the same raw materials and accessories exported from Rumania, were manufactured directly in Veneto, the number of jobs would be different because of the different productivity in the two countries. Raw materials represent roughly $50 \%$ of the turnover value in Veneto subcontracting firms. Today, employment in subcontracting clothing firms in Veneto is estimated to number around 31.000 (Crestanello, 2006). The average value added for a Veneto subcontractor is on average $20.000 €$ and the corresponding jobs in Italy needed to made the same amount of production to that which is moved to Rumania, would be 16.462 for clothing and 18.560 for footwear: so the number of employees who work in Rumania on behalf of Veneto clothing final firms amounts to more than $50 \%$ of the workers who are in Veneto. There is of course no guarantee whatsoever that without the advantages deriving from delocalization in terms of lower prices, the same products and the related jobs would have occurred in Veneto. But the estimate provides an idea of the impact of the delocalisation phenomenon on employment, both in Veneto and Rumania $^{21}$.

II: Dynamic Value Chain Analysis: Three Sector Cases.

In this section we analyse the structure of value chains in the footwear and clothing industries by presenting case-studies of firms that have delocalised their production from Italy to Rumania, through direct investments or via subcontracting relationships.

\section{II.1. Direct Investment: Geox spa.}

This first case highlights the development of a hierarchical value chain: the control is direct and the Rumanian plant uses mainly Italian machines (largely transferred from Italy) and raw materials under a (limited) Italian supervision.

\footnotetext{
${ }^{21}$ The authors provide a second estimate based on the data of turnover, export value and employment provided by the Rumanian central statistical office in 2002 and arrive at very close to the same numbers. See Crestanello and Tattara, 2005, table 7.
} 
Geox is a large international footwear producer, whose head office is located in the district of Montebelluna (Veneto). Today, Geox's production is almost completely made abroad; all sports shoes are produced in the Far East; and 80\% of leather 'classic' shoes (the main product of Geox) are manufactured in Slovenia, in a Geox factory employing 300 workers, and, also, in a recent Rumanian plant (in Timisoara) that houses 2.800 workers. All the production made abroad is imported into Italy. Geox does not have sales points in Rumania; neither does it use the domestic market in order to place faulty shoes ${ }^{22}$.

Before the fall of the Ceaucescu regime, going back to the Austro-Hungarian empire, Rumania had a flourishing footwear production, mainly concentrated in large firms such as Filty and Gubam, that until the eighties employed several thousand workers. Nowadays, only Filty has survived, halving its employment to 1400 workers. A typical pattern after the regime breakdown as previous table 4 has shown. The Geox plant therefore has been established in a rich context of footwear competences where qualified workers can be easily found or trained. Today, only 12 Italian technicians work in the Geox Rumanian plant (4\% of the total labour force), and all of them have high technical ability (all the other workers are Rumanian). Geox is interested in increasing the professional skill of its workers by using wage incentives tied to productivity. The most skilled workers belonging to a first selected group (20-25\% of the total) receive more than double the average salary of all the workers.

The Rumanian plant is completely integrated with the Italian head office. The shipment of the prototype and of the technical schedule that is realized in Montebelluna must still be made in Italy. The prototypes are the result of the work of a high-qualified staff (the Montebelluna plant employs 400, divided between designers and staff engaged in quality control and organization, as well as providing outsourced work to other local external qualified technicians and designers). In the home company, part of the staff working on classic shoes prototypes has been recruited in the Marche, which is one of the most important Italian footwear districts, far from Montebelluna and specialised in the production of classic shoes ${ }^{23}$. The Geox centre supplies the tanned leathers (coming mainly from the two main Italian tanning districts), the polyurethane necessary for the soles production, all the accessories (including the boxes for packing), the sole aluminium moulds and equipments and machinery (mainly Italian). The import of these materials into Rumania is absolutely necessary as there are not yet local firms capable of satisfying this particular demand for production inputs: as we have told almost all trade in this sector is OPT trade (table 3). According to our interviews, only shape cutters for trimming machines are produced by local mechanical firms.

Although the high level of vertical integration based on hierarchical relationships makes the exchange of information and the transfer of semi-finished products between Italy and Rumania easier, Geox management acknowledges the existence of problems and inefficiencies arising from managing a design process that is split from production. To overcome the lack of information from feedback from the production process, the Italian management is planning the

\footnotetext{
${ }^{22}$ The practice is prevented by the strict application of the OPT import clause.

${ }^{23}$ Geox has another small design centre in the Marche where 25 employees design the models and make the prototypes for its more important fashion collections.
} 
establishment of a small design department in Rumania employing local technicians coordinated by an Italian product manager. The Timisoara plant director asserts that:

Being far away, the information that is generated in the production cycle is lost, there is a break between shoe conception, design and its production realization and the attempt to establish an industrial design centre in Rumania is a rational decision to reduce such a break in the tacit knowledge transmission process.

Nearly all knowledge linkages (relating to aspects such as technical information and raw material supplies) with external enterprises (including advisers and designers) are concentrated around the Montebelluna head company; footwear machinery and raw material suppliers are almost all Italians. In Rumania, Geox uses only 6-7 footwear subcontractors. These firms are used, in addition to the internal production capacity, to satisfy the peak demands (usually in May-July) and for producing more fashionable products in shorter runs (mainly female shoes) that require high competence and ability. Half of the production outsourced in Rumania by Geox goes to firms managed by Rumanian entrepreneurs and the other half to enterprises managed by Italians. Geox helps its own subcontractors by providing them with tanned leather and accessories, machinery and, in one case, granting the use of its property.

Both the Italian and Rumanian sub-contractors are dependent on Geox within a 'captive' framework (Gereffi et al, 2004). They receive all the inputs they need in production (such as design, raw materials and accessories); they have small dimensions - except Filthy, a Rumanian firm that works also on behalf of other foreign firms; and their limited size does not allow them to enter directly onto the international market, while the domestic market is excluded - it is too poor to allow a profitable sale of quality shoes.

\section{II.2. An Italian Sub-contractor: Intercolor}

This case illustrates the way in which a discontinuity in the delocalized value chain is faced through the strength of a fiduciary relation with an Italian subcontractor that is induced to transfer abroad his activity. As a result the entire manufacturing sequence can be delocalized.

Intercolor is an industrial laundry whose manager Bruno Maule owns also a clothing company that works on behalf of some Veneto firms. Bruno Maule was a Benetton employee from 1976 to 1982. Then he worked for Marzotto and Zanella, two important Veneto firms. In 1985 Maule opened a firm producing clothing, casual trousers and shirts; the Benetton group is one of his customers. In 1993, only a few years after the fall of the Ceaucescu regime, Maule established operations in Rumania. At the beginning, he subcontracted to local enterprises; he did not go personally to Rumania, but employed an intermediary who stayed in that country two days a week, to co-ordinate the local subcontractors and explain to them the technical details for making the products. 
The Italian buyers are very strict and if the subcontractor does not stick to the standards, they send back the entire truck without too many compliments. In 1998, I gave an order to a Rumanian subcontractor that did not deliver the merchandise on time. I risked a complete failure. Then I decided to come here, to Rumania, and control and carry out the production by myself. I loaded a truck in Italy with my old firm machinery and I rented an abandoned shed, hired 12 workers, and started to produce there. I realised that I would have to stay in Rumania and I worked hard. At the beginning, workers were not able to sew properly. Here, people are accustomed to having trousers with legs of different length and out of shape - acceptable for Rumanian consumers but not for the sophisticated European market. I told my workers the importance of details. At first, they did not understand my stubbornness, but in the end I was able to respect the standards of my clients.

In Rumania, Maule started to produce 200 pairs of trousers daily for Benetton, at that time his only client. Nowadays, he produces, in a flexible way, 5000 items a day with 5 production lines and a part of the production is outsourced to two Rumanian subcontractors. Today $80 \%$ of the Benetton production is manufactured abroad, whereas in the mid nineties the quota abroad was less than $20 \%$. Benetton retains in Italy only high quality and quick time-to-market products such as flash collections and re-orders, and the remaining production is outsourced abroad (re-orders in Italy are delivered in one week's time) ${ }^{24}$.

An average production run for Intercolor consists of 4000-5000 items per mode $^{25}$. Bigger runs are an exception, such as when Maule produced in 5 months 100.000 pieces of the same model for Benetton ${ }^{26}$. The delocalization process has caused the closure of many sub-contractors in Veneto.

At the beginning, Benetton sub-contracted to Maule only the sewing phase; today Intercolor makes a finished product from cutting to packing and sends it to the Hungarian Benetton production platform, that deals with all of Eastern Europe ${ }^{27}$. The Hungarian plant receives the textiles yarns, cuts and distributes them to 50 subcontractors, mainly located in Rumania. The textile printing unit is also part of the Benetton Hungarian plant: textiles printing is nowadays required in sports fashion and the lack of textiles printing technologies is one of the main bottlenecks in the Rumanian value chain.

\footnotetext{
${ }^{24}$ Italian global buyers such as Benetton, Gas, Stefanel, Max Mara and others are not exclusively retailers and brand-owning companies, or “companies without factories”, but keep some direct manufacturing activity

${ }^{25}$ In Veneto, Benetton subcontractors produce runs of only a few hundred items.

${ }^{26}$ In Hungary, Benetton has built a production platform in order to manage relationships with subcontracting firms in PECO countries, a free exchange area with the European Union. The Hungarian plant manages around 50-55 subcontractors and is supplied from Italy with textiles, either produced by Olimpias, the textiles company of Benetton group, or directly imported from other countries outside Eastern Europe. Textiles and accessories are then distributed to all the subcontractors located in Eastern Europe. The production made in those countries are 'substituting' old French, Spanish and especially Italian production plants. On Benetton (Tattara, 2005).

${ }^{27}$ Crestanello and Dalla Libera show how the Vicenza clothing industry lost 20.000 jobs from 1990 to 2000, due to outsourcing into foreign countries (2003, p.27)
} 
Benetton Hungary carries out a sample quality control and then sends the products to Italy, where a further control is accomplished and from where the products are delivered all over the world.

Maule works also for some final firms located near Vicenza, such as Gas and Diesel. Gas - which has its own factory in the South West of Rumania - has convinced Maule, which has a laundry in Vicenza, to establish a new one in Rumania. The industrial laundry is a high capital-intensive investment, and is managed in Rumania at a cost not much less than the cost that would result if operated in Italy. However, the Italian buyers have interest in carrying out the washing in Rumania in order to complete abroad the downstream production stages that are very labour intensive. For example, jeans decolouration with an airbrush, a treatment utilising abrasive materials, is carried out piece by piece manually and the cost is very high, up to ten times the cost of a simple washing process $^{28}$. Maule is now able to complete in Rumania the whole Gas value chain, including, in addition to cutting and sewing stages, also washing and packing. The Timisoara laundry has been rebuilt and much enlarged in 2004 and now works for other foreign firms.

This example makes clear the possible contrast between the logic of comparative advantage and that of the value chain: while the logic of comparative advantage helps to explain the slice of the value chain across national borders in order to reap the lower costs (location specific), firm specific advantages explain the decision on what activities and technologies should move along the value-added chain in order to perform efficiently relative to competitors (firm specific scope economies).

The competences are not lacking as far as the employees are concerned; the Rumanian labour force is generally well trained and knowledgeable and the presence of Italian technicians is limited to just two. The Veneto entrepreneur suggests that it is not profitable in Rumania to use electronic production machines because of the high cost of their maintenance. Local workers are not able to repair them and in the case of a breakdown the firm needs to call technicians from Italy, resulting in a long delay. In addition, the higher productivity of these machines does not compensate for their cost when comparison is made with the cheap cost of Rumanian labour. In the same vein, the 'French Formen's manager in Botosani asserts that it is not useful to employ sophisticated machinery with such low cost labour, but the use of modern CAD placement and cutting stations in his factory is required by the high quality of the fabric that must not be wasted.

Maule puts out part of his production to other sub-contracting firms managed by Rumanians. In this way, he promotes the establishment of forward linkages towards domestic firms. He supplies to the subcontractors some machines that his firm does not use any more, and he sends his shop foremen to control production quality.

II.3. Three Rumanian Sub-suppliers.

\footnotetext{
${ }^{28}$ In some cases double the cost of a simple washing process (in Rumania, rising from $0.20 €$ to 2 or $3 €$ for each piece).
} 
Finally, we combine the stories of three clothing enterprises in order to demonstrate how three ex-state owned Rumanian firms were able to upgrade along the clothing value chain showing different capabilities and autonomy.

The companies, Rapsodia and Asco, are typical representatives of large Rumanian ex-state clothing enterprises that work exclusively for foreign enterprises. These companies are located in the North-East, a poor area on the Ukrainian border, and employ more than one thousand workers each. Rapsodia is managed by Rumanians who own also small equity quotas; Asco is controlled by foreign capital. In the past, these companies also produced textiles and employed a higher number of workers.

Today, both companies produce classic male clothes, receiving from their buyers all the raw materials and accessories they need, which are not available in Rumania and are imported under the OPT regime. Asco receives its clothing designs via the internet and works with its clients to develop a product for manufacture. Rapsodia receive its designs in the form of paperpatterns. Rapsodia makes a sample collection starting from a design supplied by the buyers. It prepares a real size model and develops a technical schedule which must be discussed with, and approved by, the buyer. Through such means, both Asco and Rapsodia have developed good technical competences and perform a series of roles associated with production and export activities that go beyond the pure assembly phase.

Rapsodia has recently shifted from supplying Incom, one of its previously long standing main customers, to Luck (a Mavecom spa brand) and produces casual and classic male good quality clothing. Luck used to produce in Croatia but has now brought all its delocalised production to Rumania and has transferred 5 Croatian technicians and all its high-tech machines to Rapsodia. Rapsodia has also started a subcontracting agreement for Benetton which denotes a considerable autonomy and capacity to engage with different players and product mixes.

Rather different is the situation of Confstar, a Rumanian clothing firm in Baia Mare, in Maramures, producing low quality apparel for a German brand, within a captive relationship. The German brand-owner is the only client; the products are of rather low quality (some items are also sold directly in the local market in a shop within the firm premises); and the firm has neither design nor marketing capacity.

Foreign customers of these sub-contractors have their own workers that operate permanently inside the Rumanian factories to check, at the end of each production line, the product quality. Through such means, Veneto firms have accomplished a remarkable product upgrading in Rumania. However, the director of Italpant, a Veneto enterprise of the Incotex group, previously located in Portugal and now transplanted to North East Rumania, asserts that the productivity in his factory is much higher than that existing in his Rumanian subcontracting firms, such as Rapsodia. This is partially the result of the fact that Italpant's personnel policy is based entirely on a piece-work wage while Rapsodia pays a monthly fixed wage. More generally, the existence of a productivity divergence in Rumania between enterprises controlled by Italians and enterprises organized directly by Rumanian managers is a widely diffused opinion amongst Italian technicians. Low productivity is the result of the way the 
work is organised, the premises' functionality, and the age and the type of machines in use.

Rumanian workers are generally skilled. Rumania has an important 'textiles' polytechnique in Iasci and a large supply of workers (mainly female) specialized in clothing and footwear is available. Italian sub-contractors that have come to work in Rumania have taken great advantage of these workers at a low cost. Italians who start up enterprises in Rumania, even small ones, can offer higher wages than (often larger) factories managed by Rumanians, and can attract the more qualified workers. The basic wage in Moldavia is less than $100 €$ a month and the additional cost required to attract the skilled workers is very small in terms of manufacturing cost. The larger Rumanian factories help to create a qualified labour force that is drawn upon by foreign (often small) entrepreneurs.

\section{Summary and Conclusions.}

European firms have faced strong competition from businesses in other industrial economies that are commonly outsourcing their production to low wage countries. In order to reduce production costs and keep prices competitive, German, Danish and Swedish firms began outsourcing in the eighties, but massive outsourcing began after the fall of the socialist regimes of East European countries, such as Czechoslovakia, Hungary, Poland, Rumania and Slovakia. Italian clothing and footwear firms started outsourcing later than their German and Nordic competitors, but accelerated after the advantage of the weak lira exchange rate faded away as Italy joined the EMU and the competitive pressures in the international fashion market increased.

Over the last decade, in the Veneto clothing and footwear industries, the displacement of local subcontractors due to de-localization processes, has been significant. Production phases that remain in Veneto are planning, quality control, shipment and distribution, and sometimes the high capital-intensive parts of the production process, such as weaving, dying, printing and in a few situations automatic computerised placement and cutting. In general, short series production geared to providing a quick time to market (including re-order and flash production) are not de-localized and this is also the case for some other products, such as high quality and fashionable clothes production. Also, seamless knitting - a high capital intensive process, operated by very modern machines, is still retained in Veneto (Gomirato, 2004).

De-localisation to Eastern Europe is an alternative to de-localising to far away countries, such as China. In the case of Italian footwear and clothing this process has involved a vertical process of disintegration and has maintained in Italy a large proportion of the value added. This results $t$ from the fact that the subcontracting process still utilises textiles and leather of Italian origin, universally recognized to be the best in the world in terms of quality and design, and from the fact that initial phases (such as design) and final phases (such as logistics and marketing) are still carried out in Italy. Today, 50\% and 25\% of all clothing and footwear products imported into Veneto from the low wage countries come from Rumania, and workers employed in Rumania on behalf of Veneto enterprises in these industries are estimated to number around 55.000, while the estimate for the whole of Italy reaches 120.000. Such a huge 
delocalization process in clothing and footwear brings to our attention two sets of key questions.

Firstly, in respect of the relation between outsourcing and the development of the outsourcee, we may ask: Can foreign direct investments and international subcontracting lay the ground for industrial development in the receiving country? Are they able to stimulate efficiently economic activities, complementary to the fields in which delocalization has taken place? Could the growth of domestic competences and the prospects for profits actually activate a robust autonomous growth, in a manner similar to the development process that has taken place in the Italian industrial districts?

Secondly, final firms have taken clear advantage from outsourcing abroad and their profits, subsequent to delocalization, have systematically increased (Gianelle and Tattara, 2006), but questions regarding the possible impoverishment of the outsourcing territory are nonetheless pertinent. What are the effects of such a rapid outsourcing process on the Veneto regional economy, both in terms of employment decline and loss of competences?

The main constraints on host country development due to the process of production delocalization are the lack in Rumania of organizational and entrepreneurial resources, and technical competences. Consequently, many factories in Rumania that work on behalf of foreign final firms are managed by Italians. Many small entrepreneurs who worked in Veneto as subcontractors decided to move abroad under the pressure of low prices and the threat of losing orders, but also under pressure to fill up specific gaps in the chain structure (such as laundry facilities, fabric printing, automatic cutting, and others).

Another constraint on development is the absence of a strong domestic market, and this is the key factor that explains insufficient initiative and autonomy by Rumanian producers; risk aversion and the failure to bear responsibility is a characteristic complaint by various Italian entrepreneurs in respect of Rumanian employees (Callegari, 2005).

However, Rumanian workers' professional knowledge in recent years has grown significantly; the domestic market has developed, (GDP per capita has been steadily increasing for the last since 4 or 5 years); and the range of clothing and footwear products that can now be delocalized to Rumania has broadened. Further, Rumanian industries benefit from the fact that this country is capable of producing larger production volumes than other East European countries, and have also benefited from 10 years of experience in engaging in trade relationships with Western enterprises. Rumanian textiles-clothing -footwear production currently employs approximately 500.000 workers and the country is one of the bigger textiles producers in the world, even if Rumanian enterprises have no direct access to the distribution and consumption networks at the international level and exports are under the control of foreign buyers.

The ability to sell fashion products on the international market requires marketing skills and an acquaintance with the complex fashion circuit, factors that do not find favourable conditions in poor or unsophisticated markets. And there is no reason to think, 10 years after the first experiences of production delocalization, that Rumania can become in a short while a dangerous competitor for Italy on the world international market. 
Rumania competes basically on cost elements with other low wage countries on the subcontracting and unbranded market. However, access to the European Union is considered by many entrepreneurs as one of the elements that could raise labour costs to the level of Hungary or Poland (where labour costs are 4 times higher than in Rumania) due both to an imitation process and to exchange rate stabilization. The history of the 90s' tells us that the de-localization processes directed towards some East European countries such as Hungary and Poland have, in the following years, been redirected towards Rumania and Bulgaria. A similar situation had already taken place in respect of Portugal when it joined the European Union in 1986. A significant number of French and German firms outsourced into this country their clothing production, but subsequently, when the attractiveness due to the low wages faded away, foreign enterprises redirected their production towards other countries (Thiel, Pires and Dudleston, 2000; CepsWIII, 2005, p. 94).

Of course, the above mentioned countries have changed their production structures and have subsequently hosted new kinds of less labour intensive production, but the crucial question is whether in the future Rumania will witness also a migration of production, under the control of the foreign branded firms, into lower labour cost countries, or will it expand a set of capabilities that will allow it to pursue an upgrading trajectory in clothing and footwear, as well as other sectors? The judgment of Italian entrepreneurs is not unanimous. Some entrepreneurs that govern simple value chains, and whose product does not require very short times to market, seem more prone to move production toward the lowest wage areas such as Ukraine and Moldova.

Major brand-owners who outsource large parts of their manufacturing (such as cutting, washing, ironing and packing), are well aware of the economic damage caused by mistakes in production, or by delays in sending products. These firms seek to exert a strong control over the production process, and tend to have more trust and stable relationshipsthat are built up over time. They acknowledge the advantages of the production experience in Rumania, and see them as not being equalled in any other East European country, and have convinced some of their Veneto sub-contractors to establish new firms there.

Overall, it is acknowledged that in Timisoara and Arad, where the main Italian enterprises are concentrated, a network of external economies has been created consisting of the presence of qualified workers, of services related to production, (washing, dying, transport services and accessories, mainly owned by foreigners), and of financial services provided by large foreign banks. The often alleged readiness of the Italian enterprises to search for more profitable situations, in response to the prospect of wage increases, fading fiscal incentives and new more restrictive - labour legislation, are probably more imaginary than real. If that was not so, it would mean that the increases in skills and competences, of the services, and of the infrastructures have not produced any long-lasting advantages for foreign firms. Reasonably, it can instead be assumed that Rumania can aspire to upgrade its clothing and footwear value chains, and then accommodate some of the logistic functions that today are localized in Italy.

Is the end of the multi-fibre agreement modifying this situation, moving the interest of the Veneto entrepreneurs towards China? In China, India, Bangladesh and other Asian countries, Italian firms outsource full or quasi-full production (as 
they may retain some control of the raw material supply) - what they call 'semimanufactured' - and pursue de-localization strategies, attracted by the prospects of accessing a capacity for producing high volumes at low prices. Usually raw materials and accessories are acquired in the Asian market, where it is possible to find quality and variety ${ }^{29}$.

East Asian manufacturers have for many years been coordinating the flow of orders from American and European buyers to large numbers of domestic clothing factories (Gereffi, 2002). China, although far away from the European market, with a long transportation time, can itself offer a large, rapidly developing, consumption market. China additionally is endowed with organizational resources, and an innovative capacity that make it a dangerous competitor to Rumania for attracting foreign investments.

A massive and rapid outsourcing of production activities can lead to an impoverishment of old production areas, not only in terms of employment but also in respect of knowledge and skills. The innovations that have been at the root of the 'Made in Italy' success have nearly always developed out of very close contacts between people that design and people that make; are based on product and process innovations that have arisen out of the production process; and have come out of the daily familiar use of machines and production materials. If the industrial districts lose their production competences do they run the risk of losing also their competitive advantage in designing successful products? Can a favourable scenario be reasonably assumed where Veneto textiles-clothing maintains within its own regional border the 'more high value added' production stages, such as marketing, design and logistics, and realizes in other countries the more labour intensive and less skill intensive components? The question has a solid ground because some entrepreneurs have demonstrated increasing difficulties in finding in Veneto workers with the necessary skills and knowledge, and this is a clear indication that the local pool of competences, from which the enterprises have drawn in the past, is today being diluted. ${ }^{30}$ On the other hand, firms need highly qualified people to assist their delocalisation process abroad.

Veneto enterprises de-localizing their production into a foreign country are aware of the danger of losing their technical competences, and some Italian firms, for example Marzotto, keep a part of their production in Italy in order not to lose their capabilities in making innovative products ${ }^{31}$. Many firms retain in Italy the quality control stage as well as the staff needed to assist the production transference to other countries.

Some Veneto entrepreneurs that have moved to Rumania, often far from their families, are already discussing the problem of finding their successors. It can be difficult to find people able to replace them and some entrepreneurs are thinking of selling or closing down their companies. This fact, within a few years, could change the strategic scenario of the Italian enterprises that have established their

\footnotetext{
${ }^{29}$ On the East Asian and Mexican supply chain evolution and on the threat posed by China, with its high volumes and low prices, see Gereffi $(2005,173)$.

${ }^{31}$ Just remember the German firm Baumler that outsourced to Styl in Hungary many years ago and ended up by purchasing a majority equity participation in the Hungarian firm in order to be granted access to the latter's know-how (Pellegrin 1999, p. 15)
} 
subcontracting relationships within the network of Italian entrepreneurs living in Rumania.

At home, also, the crisis in the Veneto clothing and footwear industries is generating much uncertainty and distrust, that is rendering it unappealing for young people to enter this field of activity. Furthermore, many small entrepreneurs are no longer prone to invest in plant modernization. In the past, Benetton sub-contractors were known to have renewed or increased the size of their plants, after being assured that their customer, at least for some years, would continue to provide the orders necessary to amortize the investments. Today, on the contrary, those same subcontractors are invited by Benetton to address other customers because the guarantee of stable orders is no longer available ${ }^{32}$. As a small entrepreneur from Vicenza in Veneto told us "today nobody possesses any certainties".

Bibliography:

Akamatsu K. (1962), "A historical pattern of economic growth in developing countries”, Welwirtschaftliches Archiv, v. 86.

Baldone S., Sdogati F., Tajoli L. (2001), "Patterns and Determinants of International Fragmentation of Production. Evidence from Outward Processing Trade between the EU and the Countries of Central-Eastern Europe", Weltwirtshaftliches Arkiv, v. 137

Baldone S., Sdogati F., Tajoli L. (2002), "Moving to Central-Eastern Europe: Fragmentation of Production and Competitiveness of the European Textile and Clothing Industry”, Rivista di Politica Economica, v. 92

Becattini G. and E. Rullani (1996), "Local systems and global conections: the role of knowledge”, in Cossentino F., F. Pyke and W. Sengenberger (eds.), Local and Regional Response to Global Pressure: the Case of Italy and Its Industrial Districts, Ilo, Ginevra.

Berger S., and R. M. Locke (2001), “Il Caso Italiano and Globalization” MIT IPC Working Paper 00-011, Industrial performance center.

Brusco S., S.Paba (1992), "Connessioni, competenze, capacità concorrenziale dell'industria della sardegna”, in M. D'Antonio (a cura di), Il Mezzogiorno. Sviluppo o Stagnazione?, Bologna, Il Mulino, 1992, pp. 229-275.

Callegari F. (2005), "Strategie e modelli di internazionalizzazione del distretto dello sport system di Montebelluna”, Economia e società regionale, 2.

Ceeps-WIIW. 2005. "Final Report. Part 1.The Textiles and Clothing Industries in an Enlarged Community and the Outlook in the Candidate States" (Contract No. FIF. 20030838)

Dicken P. (2003) Global Shift: Reshaping the Global Economic Map in the 21st Century, 4th edition, London: Sage Publications Ltd, page 8.

\footnotetext{
${ }^{32}$ The share of Benetton production made in Italy has declined from $80 \%$ to $30 \%$ in the last ten years and is further declining.
} 
Crestanello P. (1999) L'industria veneta dell'abbigliamento: Internazionalizzazione produttiva e imprese di subfornitura, Franco Angeli, Milano.

il caso di Vicenza”, Economia e società regionale, 2, 5-45.

Crestanello P. (2006) “Osservatorio abbigliamento Veneto”, Vicenza, First Draft

Crestanello P. and Dalla Libera P.E. (2003), "La delocalizzazione produttiva all'estero nell'industria della moda: il caso di Vicenza”, Economia e società regionale, 2, 5-45.

The Economist (2006), “Country Briefings: Romania”, Sunday April $9^{\text {th }}$.

Finger J.M. (1975), “Trade Provisions for Offshore Assembly and the Exports of Developing Countries”, AER, v.85 (338).

Finger J.M. (1977), "Offshore Assembly Provision in the West German and Netherlands Tariffs: Trade and Domestic Effects”, Weltwirtschaftliches Archiv, v. $113(2)$.

Gereffi, G. (1994), “The organization of buyer-driven global commodity chains: How US retailers shape overseas production networks”. In: G. Gereffi and M. Korzeniewicz, Editors, Commodity chains and global capitalism, Greenwood Press, Westport (1994).

Gereffi G., 2002, "The International Competitiveness of Asian Economies in the Apparel Commodity Chain”. Economics and research department working paper series no. 5

Gereffi G., J. Humphrey and T. Sturgeon (2005), "The governance of global value chains”. Review of International Political Economy, 12:1. 78-104

Gereffi G, 2005, The global economy. Organization, governance and development. In

Ginzburg A. and Simonazzi A (2003), ), "Patterns of industrialization and the flying geese model: the case of electronics in East Asia”, Journal of Asian Economics, 15(6).

Gomirato E., 2004. 'La delocalizzazione dell'abbigliamento in romania: il caso Stefanel” Economia e società regionale. n ....2, 64- 91.

Graziani G. (1998), “Globalization of production in textile and clothing industries: The case of Italian foreign direct investment and outward processing in eastern Europe”, in Zysman J., Schwartz A., Enlarging Europe: The Industrial Foundations of a New Political Reality, International and area Studies, Research Series, No. 99, University of California

Graziani G. (2001), "International Subcontracting in the Textile and Clothing Industry", in Arndt S.W., Kierzkowsky H., Fragmentation. New Production Patterns in the World Economy, Oxford. Oxford University Press.

Hirschman O.A. (1968), The Strategy of Economic Development. New Haven. Yale University Press 
Hirschman O.A. (1977), "A Generalized Linkage A to Development, with Special Reference to Staples", in Essays on Economic Development and Cultural Change in Honor of Bert F. Hoselitz, supplement to Ec. Dev. Cult. Change, vol. 25, pp 67-98.

Hirschman O.A. (1981), Essays in Trespassing: Economics to Politics and Beyond, Cambridge. Cambridge University Press.

Kaminski B., and F.Ng (2000), "Trade and Production Fragmentation: Central European Economies in EU Networks of Production and Marketing”, World Bank Discussion Paper.

Krugman P., (1995), “Growing World Trade.” Brookings Papers on Economic Activity1:327-77.

Insse (Romanian National Statistical Institute) (2003), Yearly Yearbook, www.insse.ro.

Insse (Romanian National Statistical Institute) (2004), Structural Business Survey. Design of the model for a yearly Publication "Demography of the Economic Enterprises”.

Navaretti G.B., Bruno G., Castellani D., Falzoni A. (2002), Does investing Abroad Create or Destroy Jobs at Home? The Case of Italian Multinationals, mimeo, presented to the CEPR and Centro Studi L. d'Agliano conference, 10/11 May, Turin.

Navaretti G.B., Falzoni A., Turrini A. (1999), "L’impatto della delocalizzazione nelle imprese italiane del tessile-abbigliamento e della meccanica”, Centro Studi Luca d'Agliano, Milano

Nonaka.I, H.Takeuchi (1995), The Knowledge-creating Company: How Japanese Companies Create the Dynamics of Innovation, Oxford University Press Inc, USA

Pellegrin J. (1999) "German Production Networks in Central/Eastern Europe. Between Dependency and Globalization”, Discussion Paper FS I 99-304. Wissenschaftzentrum Berlin.

Polany K. (1957), The Great Transformation, Beacon Press Boston.

Porter M.E. (1990).The Competitive Advantage of Nations. The Free Press, New York.

Prebish R. (1984), "Five Stages in my Thinking on Development”, in G. Meier and D. Seers (eds.), Pioneers in Development, Oxford University Press for the World Bank, Washington.

Regione Veneto (2006), L' identikit dell'imprenditore Veneto in Romania. $</ /$ www.regione.veneto.it/Notizie/Comunicati+Stampa/Gennaio+2006/170.htm>

Schiattarella R. (1999), "Delocalizzazione internazionale e occupazione un'analisi per i settori tradizionali italiani” in Pizzuti R. (ed.) Globalizzazione Istituzioni e coesione sociale, Donzelli, Roma. 
Schiattarella R. (1999), "La delocalizzazione internazionali: problemi di definizione e misurazione. Un'analisi per il settore del Made in Italy", in Economia e politica industriale, n. 103

Spaventa A., and S. Monni (2005), "Productive Internationalisation: Analysis of the Potential Effects on Veneto's Traditional Industrial Districts”. ISAE Monitoring Italy 2005: productivity, growth \& competitiveness

Tattara G. (2005), "Emerging hubs in central-eastern europe, trade blocs and financial co-operation”. WP Dip. Sc. Economiche. Università di Venezia.

Thiel J, Pires I and Dudleston A. (2000), "Globalisation and the Portuguese textiles and clothing filière in the post-GATT climate". In Giunta A, Lagendijk A and Pike A (eds.), Restructuring Industry and Territory: The Experience of Europe's Regions, Stationary Office, London. 109- 26

Yeats, A. J. (1998), “Just How Big Is Global Production Sharing?” Policy Research Working Paper 1871, The World Bank, Development Research Group, Washington D.C. 